UNESCO

\section{US goes back on promise}

Washington

IN spite of a public commitment to continue supporting the science programmes of UNESCO (the United Nations Educational, Scientific and Cultural Organization), or their equivalent through other channels, after the United States' resignation from the international organization with effect from 1 January this year, the Reagan administration last week requested only a token $\$ 2.7$ million in the budget it sent to Congress. The US contribution to UNESCO science programmes had been $\$ 14$ million per year, according to an analysis prepared last year by the National Academy of Sciences.

The commitment had been offered most recently by Assistant Secretary of State Gregory Newell in testimony before the

\section{Casualties in sight}

The five UNESCO programmes in which the United States wishes to continue to participate are:

- International Geological Correlation Program (IGCP)

About 80 countries participate in this project to formulate worldwide correlations of geologic strata. The programme was established largely because of the efforts of American Earth scientists; some 300 US scientists currently participate in IGCP working groups.

\section{- Intergovernmental Oceanographic} Commission (IOC)

IOC is the major mechanism for international exchange of oceanographic data. Data on subsurface ocean temperatures and salinity obtained by merchant and research ships are collected and shared; IOC also provides support for the oceanic components of the World Climate Research Program.

\section{- International Hydrological Program} (IHP)

More than 120 countries are involved in IHP, which is aimed at developing rational management of water resources; the programme is at present concerned with arid, semi-arid and humid-tropic regions. US withdrawal from UNESCO will result in loss of representation in the manning of the programme.

\section{- Man and Biosphere programme}

MAB is a vast international programme now in its twelfth year, whose stated aim is the study of the natural biosphere and man's effect upon it. Withdrawal will cost the United States its leadership positions in the programme.

\section{- Natural hazards programme}

This programme has provided US Earth scientists with the opportunity to visit areas prone to earthquakes and other natural hazards; it is directly under UNESCO management.
House of Representatives Foreign Affairs Committee last autumn. It is thought that the State Department's original budget request included the money for the science programme, but was shot down by the Office of Management and Budget.

State Department officials say they do not yet know exactly how the $\$ 2.7$ million will be allocated. But some of the money is earmarked for non-science activities, such as continued US participation in the international copyright convention. The \$2 million or so that will be left for science is expected to provide for minimal continued US participation in five UNESCO programmes: the Intergovernmental Oceanographic Commission (IOC), the International Geological Correlation Program (IGCP), the International Hydrological Program (IHP), the Man and Biosphere (MAB) programme and the natural hazards programme. A State Department official said that the aim will be to "plug the holes where US participation is essential to US interests".

But the State Department has doubts about how far $\$ 2$ million will go to meet that aim. Although there is no dispute that the United States can retain its seat on IOC, and possibly on the governing board of IGCP, it may lose influence if it does not contribute significantly to overhead costs and to new projects. In the other programmes, the United States is sure to lose its official role in management and planning. And even the $\$ 2$ million, designed to support directly the cost of participation by US scientists plus a share of overhead, falls short of the bare minimum figure of $\$ 3$ million recommended by the National Academy of Sciences report for direct contribution to these five UNESCO programmes.

The academy, moreover, recommended substantial additional support through alternative channels to make up for the US withdrawal. No such new funds are provided in the proposed 1986 budget; in fact, the National Science Foundation's budget for international cooperative research projects is to be cut from $\$ 13.6$ to $\$ 12.1$ million under the Reagan proposal, reducing participation by US scientists to 1,300 from the present 1,400 .

The academy report warned that "in order to maintain confidence in US participation in international science programs, withdrawal must be accompanied by a serious commitment, expressed in policy, institutional and budgetary terms to a continued and strengthened American role".

The UNESCO executive board is holding an emergency meeting this week to decide how to adjust its programme in the light of US withdrawal, which took 25 per cent of UNESCO's operating budget with it. State Department officials say that the US withdrawal will have no immediate effect on the participation of US scientists in UNESCO activities; the UNESCO board, however, with only $\$ 2.7$ million from the United States from next October, will probably have to cut back on some of the programmes with which the United States hopes to remain involved.

Congressional action remains a wildcard. The House Foreign Affairs Committee is scheduling hearings for later this month.

Stephen Budiansky

\section{Japanese students Choices change}

\section{Tokyo}

WHEN it comes to deciding on careers, Japan's students seem to share fully their government's faith in high technology. This year has seen a marked shift in university entrance preferences towards courses in biotechnology and the new electronic media, and companies with major biotechnology projects are zooming up the popularity charts for university graduates seeking work.

Part one of the university entrance examinations - the nationwide examinations for state universities which precede those given by individual universities - was held last week. Analysis of the major subjects according to number of applicants shows that students are reacting to the emergence of new industries almost as quickly as the Tokyo stock market. Just like the seemingly endless boom for biotechnology companies there, biotechnology-related courses are attracting more and more applicants. As many of these courses are offered in faculties of agriculture, there is a corresponding rise in their popularity, after some years in the doldrums.

Together with biotechnology, courses related to the new electronic media - the kind of services that will be offered by the information network system - are also attracting more students. The traditional "safe" careers of medicine and dentistry are seeing a sharp decline in popularity.

Much the same picture emerges from surveys of which companies students want to work in after they graduate. Although banks and insurance companies and the giant automobile and electronic makers are always among the favourites, the whisky manufacturer Suntory, which has invested very heavily in biotechnology, is now one of the three most popular companies. The high-technology ceramic maker Kyocera, a leader in the race to develop a ceramic engine, is also enjoying a sudden increase in popularity even though, like Suntory, it is not among Japan's 50 biggest companies.

The popularity of biotechnology extends to the government too. Adding together the appropriations in the budgets of all six ministries with biotechnology projects shows that spending in 1985 will reach 33,000 million yen (US $\$ 130$ million), more than 6 per cent up from last year.

Alun Anderson 